KHAZANAH MULTIDISIPLIN

VOL 2 NO 22021

https://journal.uinsgd.ac.id/index.php/kl

\title{
PERANAN YURISPRUDENSI DALAM MEMBANGUN HUKUM NASIONAL DI INDONESIA
}

\author{
Adi Rizka Permana \\ Pasca Sarjana Ilmu Hukum, UIN Sunan Gunung Djati Bandung \\ Email : adirizkapermana@gmail.com
}

Diterima : 1 May 2021, Revisi : 15 May 2021 Disetujui : 25 May 2021

\begin{abstract}
ABSTRAK
Sebagai negara yang banyak dipengaruhi oleh tradisi hukum kontinental, Indonesia memilih sendi hukumnya, baik dalam pola pengaturan maupun pembangunan hukumnya, lebih diletakkan pada fungsi dan peran hukum tertulis peraturan perundang-undangan. Namun demekian, kehadiran hukum yurisprudensi meskipun merupakan sendi dari negara dengan tradisi hukum Anglo Saxon, pada akhirnya tidak dapat dihindarkan begitu saja, karena ternyata memiliki fungsi dan peran yang sama dalam pembangunan hukum nasional. Pengakuan hukum yurisprudensi sebagai sumber hukum dan tempat menemukan hukum-hukum konkret, membuktikan keperluan bangsa ini memahaminya dengan baik. Yurisprudensi yaitu hasil akhir atau keputusan dari pengadilan, terutama (Mahkamah Agung) sebagai pengadilan tertinggi di Indonesia mengeluarkan keputusan tersebut, yang menjadi dasar pertimbangan atau keputusan para hakim untuk mengadili perkara dan oleh pengadilan yang berada di bawahnya dijadikan sumber hukum. Khususnya kepada lingkungan peradilan (para hakim) yang mengembangkan hukum melalui praktik-praktik peradilan, sudah saatnya membangun dan menciptakan hukumhukum yurisprudensi yang berkualitas.
\end{abstract}

Kata kunci : Hukum Yurisprudensi, Sistem Hukum, Sumber Hukum

\begin{abstract}
As a country that is heavily influenced by the continental legal tradition, Indonesia chooses its legal principles, both in regulating patterns and in legal development, to be more placed on the functions and roles of written law of legislation. However, the existence of jurisprudence law, although it is part of a state with the Anglo Saxon legal tradition, in the end cannot be avoided, because it turns out to have the same function and role in the development of national law. The recognition of yurisprudential laws a source of laws and a place to find concrete laws, proves the need for this nation to understand them well. Yurisprudence, namely court decision, especially decions issued by the highest state court (Supreme Court), the compilation of these decions, forms the basis for decisions of other judges to try similiar cases and becomes a source of laws for the courts below. Especially for the judiciary environment (judges) who develop law through judicial practices, it is time to build and create quality jurisprudential laws.
\end{abstract}

Keyword: Legal Yurisprudence, Legal System, Source Of Law

\section{PENDAHULUAN}

Hukum sebagai alat untuk mengubah kinerja selalu diupayakan untuk mengatasi berbagai macam masalah sosial yang ada di masyarakat (Lesmana, 2020). Kenapa dipergunakan istilah "Agent of Change" karena salah satu dalil 


\section{KHAZANAH MULTIDISIPLIN}

VOL 2 NO 22021

https://journal.uinsgd.ac.id/index.php/kl

utamanya adalah hukum selalu berusaha menyelesaikan berbagai masalah dalam dinamika perubahan yang semakin cepat setiap waktu dalam kehidupan masyarakat. Tujuan keberadaan hukum adalah untuk menciptakan kepastian hukum dan ketertiban umum. Manusia mencari keadilan dalam tingkah laku kehidupannya, terutama dalam pranata kehidupan sosial masyarakat. Adil, sebagai bangsa yang memegang teguh pendirian dan dasar negara Pancasila, adalah milik Tuhan yang eksklusif dan Tuhanlah yang dapat mewujudkan keadilan yang sejati. Dalam kasus ini, orang-orang berusaha untuk menegakkan keadilan di bumi dengan pendekatan yang paling mungkin untuk keadilan sejati. Bidang hukum merupakan wadah pembentukan lembaga peradilan bagi anggota masyarakat. Sehingga hukum terus berkembang dan perlindungan hukum yang memiliki hakikat keadilan dan kebenaran ditegaskan dalam bidang hukum materiil guna mewujudkan sistem hukum nasional.

Dalam pembangunan hukum nasional ini terdapat beberapa fungsi yaitu sebagai 1. Fungsi hukum untuk memelihara keamanan dan ketertiban, 2. Fungsi hukum untuk sarana pendidikan masyarakat dan pembangunan, 3. Fungsi hukum untuk menegakan keadilan (Ginanjar, Hanifah and Huda, 2020).

Dalam praktek hukum, ada istilah yurisprudensi yang dihasilkan oleh putusan pengadilan, khususnya putusan pengadilan negara tertinggi (MA). Putusan pengadilan tidak secara langsung melahirkan undang-undang, tetapi hanya sebagai salah satu faktor pembentukan hukum, karena putusan hakim tertinggi biasanya diikuti oleh pengadilan yang lebih rendah. Ini adalah kebiasaan yang diikuti oleh pengadilan yang lebih rendah yang menjadi kebiasaan pengadilan atau yurisprudensi.

Yurisprudensi telah lama dikenal dalam ilmu hukum. Khusus untuk studi hukum di Indonesia, istilah tersebut dikenal tidak hanya oleh perguruan tinggi negeri, tetapi juga oleh perguruan tinggi agama. Istilah ini merupakan masalah yang masih relevan untuk dilakukan kajian dalam hal praktik hukum. Mengapa, karena tampaknya belum ada kejelasan dan ketetapan dalam praktik pengadilan. Misalnya hakim harus patuh pada kasus hukum (yurisprudensi) atau tidak. Hal ini semakin mengganggu kita jika seseorang mengaitkannya dengan salah satu tujuan hukum, 
KHAZANAH MULTIDISIPLIN

VOL 2 NO 22021

https://journal.uinsgd.ac.id/index.php/kl

yaitu adanya kepastian hukum (R. Soeroso, 1993).

Pada saat yang sama, seorang hakim juga harus mandiri dalam menjalankan tugasnya. Keyakinannya tentang kebenaran yang dibuktikan dengan penilaian sebuah fakta dalam persidangan tidak boleh dipengaruhi atau didikte oleh siapa pun. Ungkapan "Demi keadilan yang berdasarkan Ketuhanan Yang Maha Esa" yang terkandung dalam setiap putusan hakim agung mengandung makna bahwa putusan yang diambil, selain mencerminkan gejolak hati nuraninya, lebih dari sekadar bukti bahwa keyakinannya dalam kebenaran yang diambil menjadi keputusan yang bertanggung jawab kepada Tuhan Yang Esa.

\section{METODE PENELITIAN}

Penelitian ini yaitu menggunakan metode dengan pendekatan kualitatif deskriptif mengenai peranan yurisprudensi dalam membangun hukum nasional di Indonesia, sehingga metode yang digunakan yaitu deskriptif analisis. Penerapan pada pendekatan di bawah ini yaitu untuk memahami dan untuk mengetahui apa dan bagaimana peranan yurisprudensi dalam membangun hukum nasional di Indonesia (Z. Ali, 2016).

\section{HASIL DAN PEMBAHASAN}

\section{Yurisprudensi}

Sebagaimana diketahui dalam setiap kajian Pengantar Ilmu Hukum, terdapat dua mazhab hukum besar di dunia ini, yaitu sistem hukum "AngloSaxon" atau "Common Law" dan sistem kodifikasi atau sistem hukum Eropa Kontinental atau juga sistem perdata. sistem keadilan. Oleh sebab itu, sebelum berbicara tentang hukum yurisprudensi, perlu dijelaskan terlebih dahulu tentang perbedaan definisi istilah yurisprudensi dalam kedua sistem hukum tersebut.

Dalam sistem hukum "Anglo-Saxon” yurisprudensi di pandang atau dipahami sebagai ilmu hukum. Sedangkan dalam sistem hukum "Eropa Kontinental" berarti yurispurdensi itu di pahami sebagai putusan pengadilan.

Dalam sistem hukum Anglo-Saxon yurisprudensi dikenal sebagai 
ilmu hukum dengan istilah atau di pahami dengan preseden. Selanjutnya dalam sistem hukum Eropa Kontinental yurisprudensi dikenal dengan putusan pengadilan sebagai acuan untuk hakim peradilan yang ada di bawahnya. Berikut ini lah pengertian yurisprudensi dalam sistem hukum eropa kontinental.

\section{Pengertian Yurisprudensi}

Dalam bahasa Latin Istilah Yurisprudensi, berasal dari kata “jurisprudentia” yang artinya yaitu pengetahuan ilmu hukum. Dalam bahasa Belanda yurisprudensi dikenal dengan istilah teknis peradilan yaitu dengan kata "jurisprudentie”. Selanjutnya istilah dalam bahasa Prancis dikenal atau dipahami sebagai "jurisprudence" yaitu peradilan tetap atau hukum peradilan (Mochtar Kusumaatmadja, 1976).

Berikut di bawah ini terdapat berbagai istilah atau pengertian yurisprudensi yang dikemukakan oleh beberapa para pakar ahli hukum yaitu sebagai berikut:

Kansil berpendapat bahwa yurisprudensi merupakan keputusan hakim terdahulu mengenai masalah atau perkara yang sama yang sering diikuti dan dijadikan dasar keputusan oleh para hakim (CST. Kansil, 1993).

Sudikno Mertokusumo mengemukakan bahwa yurisprudensi yaitu untuk penerapan hukum secara konkrit, terdapat tuntutan hak yang dilaksanakan oleh badan independen milik negara dan bebas dari pengaruh apapun atau siapapun dengan mengambil keputusan yang mengikat dan berwibawa. Singkatnya, Sudikno berpendapat bahwa yurisprudensi yaitu putusan pengadilan (Sudikno Mertokusumo, 1996).

Ridwan Halim berpendapat bahwa yurisprudensi adalah yaitu putusan hakim dalam perkara yang tidak diatur oleh undang-undang, yang selanjutnya menjadi pedoman bagi hakim lain yang menangani perkara yang sama atau serupa. (Ridwan Halim, 1998).

Surojo Wignjodipuro beranggapan bahwa putusan hakim atas suatu masalah hukum tertentu menjadi dasar putusan hakim lainnya, sehingga putusan tersebut menjelma menjadi putusan hakim tetap atas suatu hal 
atau peristiwa hukum tertentu yang terdapat dalam putusan tersebut. Ini dikenal sebagai Yurisprudensi. Yurisprudensi sebagai sumber hukum merupakan salah satu bentuk ketetapan dalam hukum ketatanegaraan Indonesia sebagai putusan hakim untuk menyelesaikan suatu sengketa tertentu. Daripada itu, keputusan hakim selalu dalam bentuk putusan dan hanya berlaku untuk hal-hal tertentu yang sedang diputuskan perselisihannya dan hanya mengikat para pihak yang berkepentingan (Surojo Wignjodipuro, 1974).

Selanjutnya, bagaimanakah dalam praktek pengadilan apa yang disebut dengan pengertian yurisprudensi. Bahkan, belum ada keterangan resmi dari Kejaksaan tentang makna yurisprudensi ini. Namun dalam berbagai pelatihan, para pejabat MA menyatakan bahwa yang dipahami yurisprudensi hanyalah putusan MA. Dalam pelaksanaannya, putusan Mahkamah Agung tersebut disusun dalam bentuk buku yang berjudul: Yurisprudensi Mahamah Agung Negara Republik Indonesia, yang disebut dengan yurisprudensi. Berdasarkan pernyataan tersebut maka ruang lingkup yurisprudensi direduksi yang menurut definisi para pakar cukup luas.

\section{Yurisprudensi dalam Sumber Hukum}

Salah satu pembahasan mengenai kajian ilmu hukum yaitu tentang sumber hukum. Sumber hukum yaitu segala sesuatu yang dibuat atau diproduksi oleh hukum atau menciptakan pertama kali hukum itu sendiri. Selain itu, sumber Hukum Kansil berpendapat bahwa sumber hukum dapat dilihat dari segi material dan formal (CST. Kansil, 1993). Yang termasuk sumber hukum formal yaitu: Undang-undang, kebiasaan, putusan hakim (yurisprudensi), dan traktat.

Berdasarkan uraian diatas maka dapat dilihat atau disimpulkan bahwa pengertian yurisprudensi yaitu merupakan salah satu sumber hukum. Dan oleh sebab itu, yurisprudensi sebagai sumber hukum dapat dimanfaatkan oleh para hakim untuk mengadili suatu kasus yang serupa, untuk pembentukan undang-undang atau peraturan lainnya oleh 
pemerintah dan dimanfaatkan sebagai dunia ilmu pengetahuan oleh para ahli atau masyarakat pada umumnya.

\section{Undang-undang, Yurisprudensi dan Putusan Pengadilan}

Seperti disebutkan sebelumnya, mengenai yurisprudensi yaitu merupakan putusan sebuah pengadilan. Seorang ahli hukum Sudikno berpendapat bahwa putusan pengadilan itu berlaku sejak dikabulkan hingga diimplementasikan. Karena putusan pengadilan mengikat para pihak yang terlibat, para pihak wajib mengakui keberadaan putusan tersebut. Setelah putusan dilakukan, itu hanya menjadi sumber hukum (Sudikno Mertokusumo, 1996).

Dengan demikian putusan pengadilan merupakan cikal bakal yurisprudensi atau terciptanya yurisprudensi sebagai hasil dari putusan pengadilan. Perbedaan antara undang-undang dengan ptusuan pengadilan, putusan pengadilan memuat aturan khusus yang hanya mengikat orang tertentu, sedangkan undang-undang memuat aturan abstrak atau umum dan mengikat semua orang.

\section{Yurisprudensi dan Aliran Hukum}

Purnadi Purbacaraka dan Soerjono Soekanto mengungkapkan sepenuhnya secara mendasar tentang apa pentingnya yurisprudensi sebagai sumber hukum dengan asumsi tentang tugas hakim. Ada beberapa asumsi mengenai jawaban atas pertanyaan tugas hakim, yaitu berkaitan dengan tiga mazhab atau aliran hukum yaitu sebagai berikut: (Purnadi Purbacaraka dan Soerjono Soekanto, 1993).

\section{Aliran Legismee}

Dalam mazhab ini, menyebutkan bahwa yurisprudensi tidak terlalu penting sebab aliran ini mengasumsikan semua hukum telah dimasukkan ke dalam undang-undang. Hakim terikat oleh undang-undang dan metode berpikir deduktiflah yang digunakan para hakim dalam menjalankan tugasnya. Selanjutnya mazhab ini, beranggapan bahwa ilmu yang utama tentang hukum yaitu pengetahuan tentang undang-undang, sehingga dalam mempelajari jurisprudensi merupakan masalah sekunder. 
KHAZANAH MULTIDISIPLIN

VOL 2 NO 22021

https://journal.uinsgd.ac.id/index.php/kl

\section{Aliran Freie Rechtslehre}

Mazhab ini sebenarnya merupakan perkembangan dari aliran legisme yang dipengaruhi oleh aliran Freie Rechtslehre. Perkembangan ini disebabkan karena pemikiran hukum harus didasarkan pada prinsip keadilan masyarakat yang terus berkembang, karena tampaknya pembuat undang-undang tidak dapat mengikuti perubahan jaman atau kecepatan pergerakan masyarakat atau proses pembangunan sosial, dengan begitu undang-undang selalu tertinggal oleh perkembangan masyarakat. Setiap masalah yang muncul selalu tidak bisa di pecahkan atau diselesaikan oleh undang-undang. Undang-undang tidak selalu lengkap dan tidak bisa mencakup semuanya yang mengakibatkan terjadinya kekosongan dalam undang-undang, sehingga hakim harus menyusunnya dengan melakukan rekonstruksi hukum untuk mengisi kekosongan tersebut. Dalam aliran ini yurisprudensi menjadi suatu hal yang utana dibandingkan dengan undangundang.

\section{Aliran Rechtsvinding}

Dalam mazhab yang ketiga ini, hakim diwajibkan taat terhadap undang-undang, tetapi tidak seketat apa yang disebutkan dalam mazhab legisme, hakim bebas dalam menjalankan tugasnya. Namun, kebebasan yang dipahami bukanlah yang dipahami dalam aliran kedua atau aliran freie rechtslehre. Menurut aliran ketiga ini, kebebasan bukan kebebasan yang absolut tetapi tetap masih terikat. Ketika hakim mampu menyelaraskan atau menyesuaikan undang-undang dengan tuntutan zaman disitulah terciptanya atau tercerminnya kebebasan hakim.

Dalam mazhab ini pemahaman hukum hanya di bidang perundangundangan saja, tanpa mempelajari jurisprudensi belum lengkap. Oleh karena itu, menurut mazhab ini pengetahuan tentang jurisprudensi juga penting. Hal ini disebabkan adanya garis hukum atau perkara hukum yang berlaku di masyarakat, namun tidak ada atau tidak terbaca di dalam undang-undang. 
KHAZANAH MULTIDISIPLIN

VOL 2 NO 22021

https://journal.uinsgd.ac.id/index.php/kl

\section{Kriteria Jurisprudensi}

Telah kita tahu bahwa jurisprudensi yaitu merupakan hasil akhir dari pengadilan atau singkatnya bisa disebut dengan putusan pengadilan yang sudah ingkrah. Yang jadi pertanyaannya apakah semua putusan pengadilan bisa dikatakan jurisprudensi. Achmad Ali seorang ahli hukum membagi jurisprudensi menjadi dua macam yaitu sebagai berikut: (Achmad Ali, 1996).

1. Juriprudensi biasa, yaitu merupakan semua putusan pengadilan yang sudah mempunyai atau memeiliki kekuatan pasti yaitu seperti semua putusan Mahkamah Agung, putusan pengadilan tinggi dan pengadilan negeri (agama) yang tidak dibanding dan yang tidak dikasasi, dan putusan tentang perdamaian di dalam perkara perdata.

2. Jurisprudensi tetap, bisa dikatakan semua putusan hakim dalam suatu hal perkara yang sama yang harus diikuti oleh hakim berikutnya.

Menurut Achmad Ali, semua putusan akhir pengadilan yang memiliki kekuatan hukum tetap dapat dikualifikasikan sebagai jurisprudensi baik putusan pengadilan tingkat pertama, putusan banding maupun putusan kasasi. Tidak ada perbedaan apakah keputusan ini diikuti oleh hakim berikutnya atau tidak ketika terjadinya kasus yang sama atau sejenis.

Namun, menurut hasil laporan penelitian menyebutkan bahwa tidak semua putusan dapat dikategorikan sebagai jurisprudensi. Penelitian tersebut dilakukan oleh akademisi sarjana hukum dengan mengambil sample atau responden dari semua hakim yang berada di Pengadilan Negeri se wilayah Jakarta. Adapun suatu putusan hakim yang dikategorikan sebagai yurisprudensi apabila keputusan tersebut mempunyai lima unsur yang harus dipenuhi yaitu sebagai berikut:

1. Keputusan tentang sesuatu yang belum diatur dengan jelas

2. Merupakan suatu keputusan yang tetap

3. Keputusan yang berulang telah diambil berdasarkan perkara serupa

4. Terwujudnya rasa keadilan 
5. Keputusan tersebut dibenarkan oleh Mahkamah Agung.

Namun jika dilihat makna Jurisprudensi dalam prakteknya sebagaimana tersebut di atas, ternyata bahwa ruang lingkup jurisprudensi tersebut lebih terbatas yaitu hanya pada putusan Mahkamah Agung Republik Indonesia. Di satu sisi, secara garis besar yaitu semua putusan MA, terlepas dari apakah putusan tersebut atas sesuatu belum jelas, apakah putusan tersebut digunakan sebagai alat untuk memutus kasus yang serupa oleh hakim berikutnya, atau apakah memenuhi rasa keadilan atau tidak.

\section{Putusan Pengadilan (Yurisprudensi) dalam Sistem Peradilan Di Indonesia}

\section{Yurisprudensi sebagai Sumber Hukum Di Indonesia}

Dalam sistem peradilan di Indonesia, undang-undang merupakan sumber utama hukum. Namun, sebagaimana diakui oleh para ahli hukum, salah satu ciri atau sifat hukum adalah rawan keusangan sehingga selalu ketinggalan oleh perkembangan zaman dan teknologi. Bersamaan dengan itu, permasalahan baru bermunculan seiring dengan berkembangnya arus globalisasi yang meliputi semua aspek kehidupan, misalnya di bidang ekonomi, teknologi dan masyarakat. Masalah baru ini tidak ada saat undang-undang diberlakukan. Tentu saja tidak semua jawaban atas masalah baru didapat dari undang-undang tersebut.

Adanya asas hukum yang menggambarkan hakim sebagai orang yang mengetahui hukum (ius curia novit). Penerapan prinsip ini adalah bahwa hakim sebagai salah satu penegak hukum tidak dapat menolak untuk memeriksa suatu perkara karena hukumnya tidak ada atau tidak jelas. Jika dia dituduh memiliki masalah, seorang hakim harus memutuskannya. Dan keputusan ini tidak hanya bertanggung jawab kepada masyarakat tetapi juga kepada Tuhan Yang Maha Esa. Masalahnya adalah apa yang terjadi ketika hukum tidak ada dalam undang-undang atau hukum tersebut ada dalam undang-undang, tetapi ketika diterapkan bertentangan dengan makna keadilan dalam masyarakat.

Memberikan kesempatan kepada hakim untuk menciptakan atau 
menemukan hukum yang baru melalui ijtihad hukum. Ijtihad hukum ini, jika kemudian diputuskan dan disahkan oleh Mahkamah Agung, kemudian menjadi rujukan bagi hakim lain yang mengadili perkara sejenis untuk menjadi jurisprudensi. Hal tersebut tertuang dalam Undang-undang No. 38 Tahun 2009 Tentang Kekuasaan Kehakiman.

Yahya Harahap mengemukakan mengenai yurisprudensi, bahwa sebuah yurisprudnsi jika benar-benar memuat gagasan dasar bersama yang mempunyai dua dimensi yang memperhatikan nilai-nilai dasar cita-cita Pancasila dan UUD 1945 yang dipadukan dengan nilai-nilai globalisasi, maka perpaduan tersebut menghasilkan. formula hukum yang rasional. Dalam praktiknya, sudah sepantasnya hakim harus mengikutinya. Selanjutnya Yahya Harahap, mengemukakan tentang apa yang disebut dengan fungsi yurisprudensi yaitu berfungsi untuk menciptakan standar hukum, berfungsi untuk mencapai kesamaan dasar hukum dan keseragaman gagasan hukum yang sama, dan untuk menegakan kepastian hukum. (M. Yahya Harahap, 1995).

\section{Kebebasan Hakim dalam mengikuti Yurisprudensi}

Hakim adalah salah satu instrumen yang disahkan oleh undangundang untuk menjalankan kekuasaan kehakiman. Dalam menjalankan fungsinya bersifat independen dalam arti bebas dari campur tangan otoritas negara lain dan dari segala kendala, arahan atau rekomendasi dari pihakpihak di luar negara hukum, kecuali hal tersebut diizinkan oleh undangundang.

Selanjutnya ada empat makna pengertian tentang kebebasan hakim yaitu sebagai beriku:

1. Baik secara material maupun formal tidak dipengaruhi oleh pihakpihak yang terlibat dalam kasus tersebut

2. Tidak terpengaruh oleh tekanan, eksekutif atau rekomendasi dari pihak diluar pengadilan, dari siapapun atau dari intansi manapun.

3. Memberikan Kebebasan dan keberanian kepada hakim untuk berinisiatif dan meningkatkan tugas penyidikan dan memutus suatu 
perkara bagi perkembangan hukum itu sendiri, untuk memberikan rasa keadilan dan kebenaran, untuk eksistensi suatu negara dan bangsa yang merdeka dan berdaulat.

4. Kebebasan untuk dibertanggung jawabkan atas nama lembaga dan diri sendiri, kepada masyarakat, negara, bangsa dan kepada Tuhan Yang Maha Esa (Mahkamah Agung, 2005).

Sampai sejauh mana kebebasan hakim, Yahya Harahap berpendapat bahwa masa kebebasan hakim yang mandiri untuk menjalankan fungsi kehakiman mencakup lima hal yaitu sebaai berikut: (M. Yahya Harahap, 1995).

1. Interpretasi atau menafsirkan peraturan perundang-undangan

2. Prinsip dan dasar hukum harus dicari dan ditemukan

3. Membuat hukum yang baru ketika terjadi kekosangan perundangundangan

4. Bertindak mengesampingkan peraturan perundang-undangan yang berlaku jika ketentuan pasal-pasal hukum bertentangan dengan kepentingan masyarakat atau publik

5. Bebas untuk mengikuti yurisprudensi.

Sudikno Mertokusumo, mengemukakan pendapatanya bahwa hakim dalam sistem hukum Indonesia pada prinsipnya tidak terikat dengan putusan hakim sebelumnya dalam perkara atau masalah hukum serupa yang akan diputuskan. Meski begitu, hakim junior dalam praktek di lingkungan peradilan Indonesia selalu mengikuti pandangan Mahkamah Agung (MA) dalam menyelesaikan perkara yang sama karena alasan sebagai berikut:

1. Mahkamah Agung (MA) adalah penyelenggara lembaga peradilan tertinggi yang diberi wewenang untuk membina dan memajukan peradilan

2. Hakim agung dinilai lebih memiliki kewenangan dalam urusan hukum

3. Jika putusan atau pendapat Mahkamah Agung tidak diikuti, Mahkamah Agung bisa berpotensi membatalkan suatu putusan hakim 
yang ada di bawahnya apabila sampai ke Mahkamah Agung (Sudikno Mertukusumo, 1996).

\section{Asas-Asas dalam Yurisprudensi}

Bagian ini juga mengutip secara lengkap apa yang dikatakan Purnadi Purbacaraka dan Soerjono Soekanto, di mana dalam praktik bernegara masalah peradilan ditangani menurut asas-asas tertentu. Asas utama atau terpenting yang dapat dipertimbangkan atau dipegang oleh suatu negara kaitannya dengan peradilan dapat berupa asas presedent dan asas bebas. Dibawah ini merupakan penjelasan singkat tentang kedua asas tersebut yaitu:

\section{Asas Presedent}

Asas preseden, yang diadopsi oleh negara-negara Anglo-Saxon yaitu seperti Inggris Raya, Amerika Serikat, menyiratkan bahwa pejabat kehakiman (hakim) wajib taat dan mengikuti putusan hakim yang lebih tinggi sebelumnya (stare decisis) peraturan tersebut berlaku di negara Anglo-Saxon yang menganut sistem “common law”. Terdapat pengecualian atas batasan asas presedent yaitu sebagai berikut:

Jika keputusan sebelumnya diterapkan pada suatu perkara atau peristiwa yang dianggap tidak masuk akal dan tidak menyenangkan

Selama diktum yang bersangkutan yaitu ketika hakim mengatakan bahwa tidak perlu ada keputusan. Dengan penjelasannya yaitu diktum tidak pernah berkurang, otoritas harus dihormati dan salah jika menganggapnya diabaikan. Ini dapat diikuti oleh pengadilan dalam kasus-kasus mendatang, seringkali cukup untuk membujuk pengadilan yang lebih rendah, dan dapat dilihat oleh pengacara sebagai dasar yang dapat diandalkan untuk konseling. Tapi itu hanya otoritas persuasif.

\section{Asas Bebas}

Asas bebas, yang artinya yaitu merupakan kebalikan dari asas sebelumnya yaitu asas preseden. Menurut asas bebas ini, aparat kehakiman atau peradilan tidak terikat oleh keputusan hakim yang setara atau otoritas yang lebih tinggi. Asas ini diadopsi oleh negara yang menganut sistem "Civil 
Law" atau Eropa Kontinental yaitu seperti negara Prancis, Belanda, dan Indonesia. Asas bebas ini berarti bahwa seorang hakim tidak selalu terikat oleh keputusan hakim lainnya, yang setara atau otoritasnya yang lebih tinggi. Kata independen di sini berarti hakim dalam memutus suatu kasus atau perkara dapat mengikuti putusan hakim sebelumnya, baik pada level yang setara maupun pada level otoritasnya yang lebih tinggi, dan juga boleh tidak mengikuti putusan hakim sebelumnya (Abdul Rahman Budiono, 2005).

Ketika seorang hakim mengikuti putusan hakim yang lain atau hakim sebelumnya yang sederajat atau otoritasya lebih tinggi, itu dikarenakan mempunyai berbagai alasan tertentu yaitu sebagai berikut: (Dudu Duswara Machmudin, 2000).

Karena secara psikologis berarti hakim memiliki kekuasaan, apalagi jika putusan yang diambil oleh otoritas peradilan yang lebih tinggi seperti pengadilan tinggi atau Mahkamah Agung (MA)

Karena secara praktis, yaitu seorang hakim junior yang berada di tingkat pengadilan negeri secara logis mengikuti putusan yang dibuat oleh hakim yang lebi senior atau jabatannya lebih tinggi yang berada di tingkat peradilan lebih tinggi

Karena adanya keyakinan bahwa seorang hakim sebagai pemutus perkara sejalan dan sependapat dengan keputusan hakim sebelumnya.

Di Indonesia sebenarnya asas preseden dan asas bebas ini sudah dikenal dan diimplementasikan dalam sistem peradilan Indonesia, dan pelaksanaannya dapat di temukan dalam peradilan hukum adat menggunakan asas preseden, sedangkan dalam pelaksanaan peradilan umum menggunakan asas bebas.

\section{SIMPULAN}

Suatu jurisprudensi yang berperan penting dalam hukum pemerintahan di peradilan Indonesia, yaitu yurisprudensi yang berkaitan dengan asas-asas hukum pemerintahan yang baik. Terkait hukum good governance, Mahkamah Agung ini telah lama ditegakkan melalui 
KHAZANAH MULTIDISIPLIN

VOL 2 NO 22021

https://journal.uinsgd.ac.id/index.php/kl

mekanisme kelembagaan. Mengenai independensi hakim, perkara hukum pada hakikatnya tidak merongrong nilai-nilai independensi hakim. Akibatnya yurisprudensi yaitu merupakan penyempurnaan hukum, di dalamnya terdapat norma hukum yang mengikat hakim, sehingga tidak dapat dikatakan hakim tidak independen ketika hakim memutuskan untuk mempertimbangkan yurisprudensi.

Selanjutnya jurisprudensi digunakan sebagai pedoman bagi hakim untuk memutuskan suatu perkara. Dengan pegangan atau pedoman yang ada di lembaga peradilan maka sikap lembaga peradilan akan timbul konsistensi dan keputusan yang kontroversial akan dihindari, yang pada akhirnya bisa menjamin kepastian hukum dan kepercayaan pada lembaga peradilan dan penuntutannya baik di forum nasional maupun terutama di tingkat internasional.

\section{DAFTAR PUSTAKA}

Ali, Achmad. (1996). Menguak Tabir hukum (Suatu kajian Filosofis dan Sosiologis). Jakarta: PT Gunung Agung.

Ali, Z. (2016). Metode Penelitian Hukum. Jakarta: Sinar Garfika.

Budiono, Abdul Rahman. (2005). Pengantar Ilmu Hukum. Malang: Bayumedia Publishing.

Ginanjar, D., Hanifah, F., \& Huda, U. N. (2020). DIMENSI PEMILU DALAM SISTEM DISTRIK DAN PROPORSIONAL. Khazanah Multidisiplin, 1(1), 21-30.

Halim, Ridwan. (1998). Tanya Jawab Ilmu Hukum. Jakarta: Ghalia Indonesia.

Harahap, M.Yahya. (1995). Peran Yurisprudensi sebagai Standar Hukum Sangat Penting Pada Era Globalisasi, ( dimuat dalam Pustaka Peradilan).

Kansil, CST. (1993). Tanya Jawab Pengantar Ilmu Hukum. Jakarta: Sinar Grafiti.

Kusumaatmadja, Mochtar. (1976). Hukum, Masyarakat dan Pembinaan Hukum Nasional, Suatu uraian tentang Landasan Pikiran, Pola dan Mekanisme Pembaharuan Hukum di Indonesia. Bandung: Binacipta.

Lesmana, R. M. (2020). PENERAPAN ASAS ULTIMUM REMEDIUM PADA PELAKU TINDAK PIDANA PELANGGARAN BAKU MUTU LIMBAH (ANALISIS PASAL 100 UU 32 TAHUN 2009). Khazanah Multidisiplin, 1(1), 31-45. 


\section{KHAZANAH MULTIDISIPLIN}

VOL 2 NO 22021

https://journal.uinsgd.ac.id/index.php/kl

Machmudin, Dudu Duswara. (2000). Pengantar Ilmu Hukum Sebuah Seketsa. Bandung: PT. Reffika Adiatama.

Mahkamah Agung. (2005). Naskah Akademis Tentang Pembentukan Hukum Melalui Yurisprudensi. Jakarta: Mahkamah Agung.

Mertokusumo, Sudikno. (1996). Mengenal Hukum. Yogyakarta: Liberti.

Purbacaraka, Purnadi dan Soerjono Soekanto. (1993). PerundangUndangan dan Yurisprudensi Bahan P.T.H.I. Bandung: PT Citra Aditya Bakti.

R. Soeroso. (1993). Pengantar Ilmu Hukum. Jakarta: PT. Sinar Grafika.

Wignjodipuro, Surojo. (1974). Pengantar Ilmu Hukum. Bandung: Alumni. 